\title{
A REporter Immobilization Assay (REIA) for Bioconjugating Reactions
}

Martin Schatte*ab, Marco Bocola ${ }^{\mathrm{a}}$, Teresa Roth ${ }^{\mathrm{b}}$, Ronny Martinez ${ }^{\mathrm{a}}$, Erhard Kopetzki ${ }^{\mathrm{c}}$, Ulrich Schwaneberg*a and Mara Bönitz-Dulat*b

${ }^{a}$ Lehrstuhl für Biotechnologie, RWTH Aachen University, 52074 Aachen, Germany

${ }^{\mathrm{b}}$ Enzymes and Protein Technologies, Roche Diagnostics GmbH, 82372 Penzberg, Germany

${ }^{c}$ Large Molecule Research, Roche Diagnostics GmbH, 82372 Penzberg, Germany

Corresponding Author

*E-mail: Martin.Schatte@roche.com

*E-mail: Mara.Boenitz-Dulat@roche.com

*E-mail: U.Schwaneberg@biotec.rwth-aachen.de

\section{SI}

\section{Emmerson of Cy5 at $630 \mathrm{~nm}$ excitation}

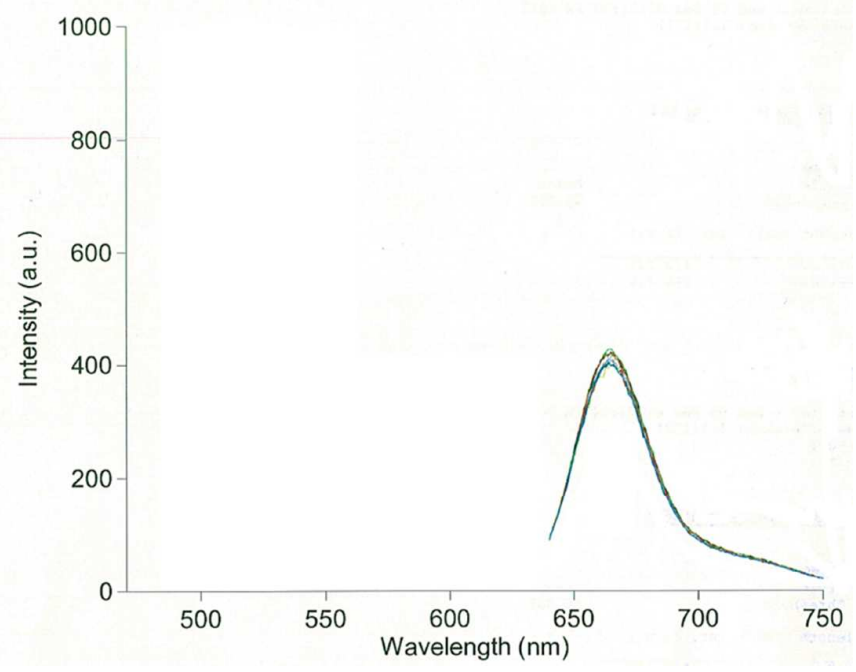

Figure S1. Emission spectra (excitation: $630 \mathrm{~nm}$ ) of the sortase reaction mixture ca. $50 \mu \mathrm{M}$ Cy5-LPETGGGRRC-FITC, ca. $50 \mu \mathrm{M}$ GGGWW-BHQ 2 and $10 \mu \mathrm{M}$ Sa-SrtA monitored over $7 \mathrm{~h}$.

\section{FRET Peptides tested}

\begin{tabular}{|c|}
\hline Cy5-ULPETGGGRRC-OH \\
\hline LCR640-ULETGGGRRC(FITC)-OH \\
\hline LCR640-ULETGGGRRC-OH \\
\hline H-GGGWWK(FITC)-OH \\
\hline
\end{tabular}




\section{Background of REIA}

\begin{tabular}{|l|r|r|}
\cline { 2 - 3 } \multicolumn{1}{c|}{} & \multicolumn{1}{c|}{ Beads } & \multicolumn{1}{c|}{ MTP } \\
\cline { 2 - 3 } & 0.0012 & 0.0090 \\
\cline { 2 - 3 } & -0.0006 & 0.0093 \\
\cline { 2 - 3 } & 0.0021 & 0.0110 \\
\cline { 2 - 3 } & 0.0016 & 0.0097 \\
\cline { 2 - 3 } & 0.0033 & 0.0093 \\
\cline { 2 - 3 } & 0.0022 & 0.0093 \\
\hline Mean & 0.0016 & 0.0096 \\
\hline $\begin{array}{l}\text { standard } \\
\text { deviation }\end{array}$ & 0.0016 & 0.0096 \\
\hline
\end{tabular}

Table S2. Background of Beads and MTP.

To monitor the background of the different REIA formats the assay was performed as described in "REIA as Sortase activity assay or REIA as high-throughput screening assay in crude cellular extract" without the addition of sortase or lysate, respectively. Resulting activities are shown. 


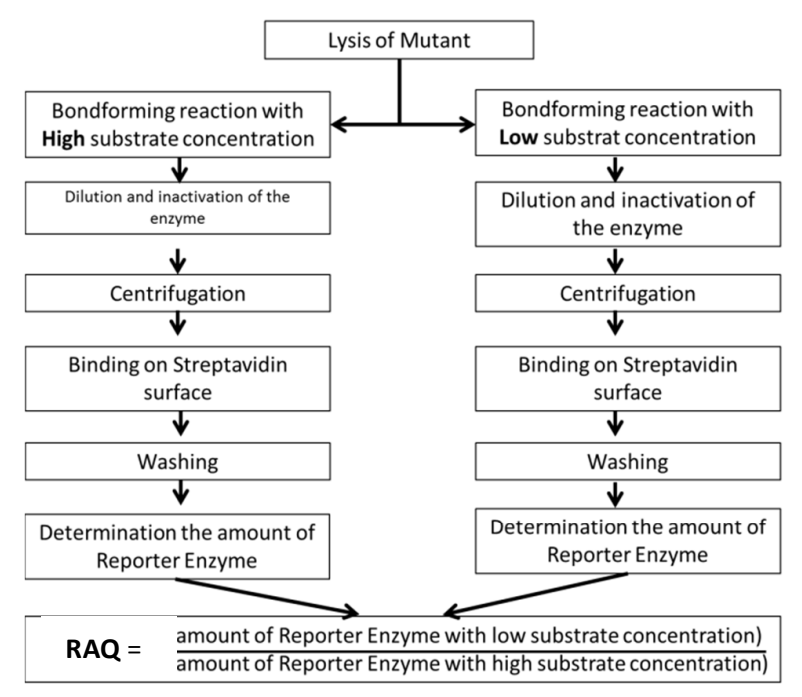

Figure S2. Experimental determination strategy and calculation of "Relative Affinity Quotient " RAQ

\section{RAQ determination}

\section{Sa-SrtA $\Delta 59$ WT}

\begin{tabular}{|c|c|c|}
\hline $\begin{array}{c}\text { Activity with } \\
20 \mu \mathrm{M} \text { Substrate }\end{array}$ & $\begin{array}{c}\text { Activity with } \\
4 \mu \mathrm{M} \text { Substrate }\end{array}$ & $\mathrm{RAQ}$ \\
\hline 0,0375 & 0,0080 & 0,212 \\
\hline 0,0533 & 0,0122 & 0,229 \\
\hline 0,0397 & 0,0094 & 0,236 \\
\hline 0,0392 & 0,0091 & 0,233 \\
\hline 0,0510 & 0,0128 & 0,252 \\
\hline 0,0374 & 0,0082 & 0,218 \\
\hline 0,0748 & 0,0187 & 0,250 \\
\hline 0,0432 & 0,0118 & 0,274 \\
\hline 0,0854 & 0,0193 & 0,227 \\
\hline 0,0402 & 0,0100 & 0,248 \\
\hline 0,0330 & 0,0094 & 0,286 \\
\hline 0,0365 & 0,0090 & 0,246 \\
\hline 0,0550 & 0,0162 & 0,295 \\
\hline 0,0469 & 0,0103 & 0,220 \\
\hline 0,0576 & 0,0121 & 0,210 \\
\hline 0,1192 & 0,0267 & 0,224 \\
\hline \multicolumn{2}{|c|}{ mean } & 0,241 \\
\hline \multicolumn{2}{|c|}{ standard deviation } & 0,025 \\
\hline
\end{tabular}

\section{Sa-SrtA $\Delta 59$ P94S}

\begin{tabular}{|c|c|c|}
\hline $\begin{array}{c}\text { Activity with } \\
20 \mu \mathrm{M} \text { Substrate }\end{array}$ & $\begin{array}{c}\text { Activity with } \\
4 \mu \mathrm{M} \text { Substrate }\end{array}$ & $\mathrm{RAQ}$ \\
\hline 0,0132 & 0,0048 & 0,3615 \\
\hline 0,0150 & 0,0050 & 0,3320 \\
\hline 0,0133 & 0,0047 & 0,3549 \\
\hline 0,0131 & 0,0048 & 0,3641 \\
\hline 0,0177 & 0,0063 & 0,3554 \\
\hline 0,0149 & 0,0055 & 0,3703 \\
\hline 0,0135 & 0,0046 & 0,3395 \\
\hline 0,0137 & 0,0046 & 0,3339 \\
\hline 0,0137 & 0,0046 & 0,3343 \\
\hline 0,0162 & 0,0056 & 0,3470 \\
\hline 0,0144 & 0,0052 & 0,3647 \\
\hline 0,0151 & 0,0054 & 0,3557 \\
\hline 0,0152 & 0,0050 & 0,3293 \\
\hline 0,0189 & 0,0062 & 0,3271 \\
\hline 0,0142 & 0,0050 & 0,3514 \\
\hline 0,0144 & 0,0052 & 0,3652 \\
\hline \multicolumn{2}{|c|}{ mean } & 0,3492 \\
\hline standard deviation & 0,0145 \\
\hline
\end{tabular}

Table S3. Detailed data for RAQ $\mathbf{Q}_{\text {Sort-tag. }}$

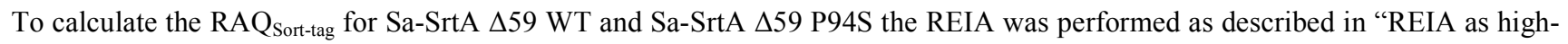
throughput screening assay in crude cellular extract" with $4 \mu \mathrm{M}$ and $20 \mu \mathrm{M}$ Sort-tag-substrate. Resulting activities and RAQsort-tag are shown. 


\section{Evaluation of the binding behavior on the Streptavidin coated MTP}

Cells (E.coli BL21) expressing sortase were cultured (overnight, 11 shaking flasks filed with $200 \mathrm{ml} \mathrm{LB}-\mathrm{media}, 37^{\circ} \mathrm{C}, 160 \mathrm{rpm}$ ). The cell suspension was mixed 1:10 with lysis buffer and incubated $\left(50{ }^{\circ} \mathrm{C}, 30 \mathrm{~min}\right)$. Lysate $(50 \mu \mathrm{l})$ was mixed with substrate solution containing $20 \mu \mathrm{M}$ of glucose dehydrogenase-LPXTG and $20 \mu \mathrm{M}$ GGG-biotin substrates and incubated ( $37^{\circ} \mathrm{C}$, $\left.2 \mathrm{~h}\right)$. The reaction was stopped by addition of a 20 -fold excess of inhibition buffer. The stopped reaction mixture was centrifuged (5000 g, $10 \mathrm{~min})$. The supernatant $(50 \mu \mathrm{L})$ was transferred to a streptavidin coated microtiter plate and $100 \mu \mathrm{L}$ assay buffer were added and incubated $\left(30^{\circ} \mathrm{C}, 200 \mathrm{rpm}, 5-30 \mathrm{~min}\right)$. Thereafter the microtiter plate was washed eight times with $300 \mu \mathrm{L}$ washing buffer. After washing, $150 \mu \mathrm{L}$ test buffer were added. Initial reaction rates of the reporter enzyme (glucose dehydrogenase) were measured over a time period of $5 \mathrm{~min}$ at $620 \mathrm{~nm}$.

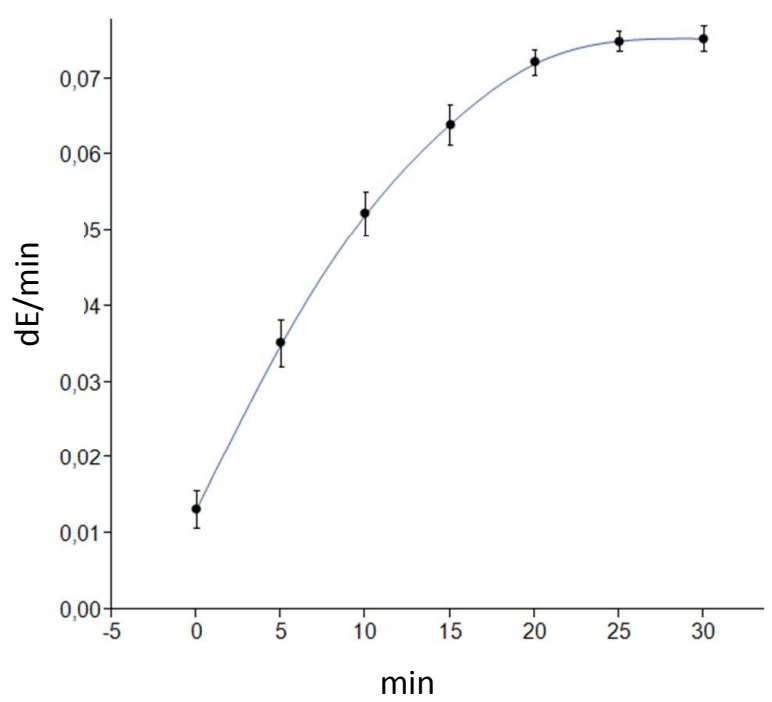

Figure S3. Time dependence of immobilization. The stopped reaction mixture was added on to the Streptavidin-MTP and incubated for 0-30 $\min$ at $30^{\circ} \mathrm{C}$ and $200 \mathrm{rpm}$. Afterwards the plates were washed and analyzed for the reporter enzyme activity. Standard deviation of 8 independent measurements is shown in the error bars. 